\title{
Analysis Of Knowledge And Attitudes On Perineal Wound Healing In Postpartum Mother In The Area Of Pekauman Public Health Center In South Banjarmasin
}

Yayu Puji Rahayu ${ }^{1 *}$

${ }^{1}$ Academy of Midwifery Sari Mulia Banjarmasin, Indonesia

*yp_rahayu@akbidsarimulia.ac.id

Rina Saputri ${ }^{2}$

${ }^{2}$ STIKES Sari Mulia, Banjarmasin Indonesia

Rina_saputri@stikessarimulia.ac.id

Nur Rahmadaniah ${ }^{2}$

${ }^{2}$ STIKES Sari Mulia, Banjarmasin Indonesia

Nur_rahmadaniah@gmail.com

\begin{abstract}
Objective: To analyze the analysis of knowledge and attitudes of perineal wound healing in postpartum mother in area Pekauman public health center in South Banjarmasin.

Method: This study used an analytic survey with cross-sectional approach. Population and sample are postpartum mothers with Perineum wound of degree I and II in working area of Puskesmas Pekauman South Banjarmasin on March-April 2017 amount 30 people, taken by purposive sampling technique, the amount of sample that is used is a minimal sample. Data that is obtained use Spearman rank test with $95 \%$ level of credibility.

Results: The analysis is used spearman rank test with $95 \%$ value of credibility. There is a correlation between maternal knowledge and Perineum wound healing $(p=0,001 \alpha=0,561)$ and correlation between postpartum attitude toward perineal wound healing $(\mathrm{p}=0,003 \alpha=0,523)$.

Conclusion: There is an Analysis between knowledge and postpartum attitude toward Perineumwound healing in area Puskesmas Pekauman South Banjarmasin.
\end{abstract}

Keywords: Attitude, Knowledge, Perineum Wound Healing, Post Partum.

\section{INTRODUCTION}

The postpartum period (puerperium) begins after the birth of the placenta and ends when the uterus returns to its prepregnancy state. Puerperium period begins 2 hours after the birth of the placenta up to 6 weeks (42 days) after that. In Latin, a certain start time after childbirth is called Puerperium that is from Puer word which means baby and Parous give birth. So, puerperium means the time after giving birth to a baby. Puerperium is a time of recovery, from labor to completion until reproductive devices such as pre-pregnant. Approximately $50 \%$ of maternal deaths occur within the first 24 hours of postpartum so that quality postpartum care must be established at that time to meet the needs of mothers and infants. [1]

Data World Health Organization (WHO), showed $74 \%$ of AKIs due to complications during pregnancy and maternity and 25\% during Post Partum period. Maternal Mortality Rate (MMR) in Indonesia is still high, according to data from Indonesia Demographic Health 
Survey (SDKI) in 2015 maternal mortality reached 305 per 100,000 live births. The cause of maternal death was bleeding $(27 \%)$, infection $(11 \%)$, eclampsia (23\%), old parts 5\%), obstetric trauma (5\%), abortion (8\%), embolism obstetrics (5\%) and other causes (11\%). Births in Indonesia who receive postpartum health services or postpartum visit (KF) in full include KF1, KF2, and KF3 that is $87.06 \%$. Postpartum periods which are at risk for postpartum complications mainly occur on the 3rd day after delivery. The coverage of postpartum KF3 health care varies by South Kalimantan province $(85,45 \%)$, the highest in the Riau Islands (112,89\%) and the lowest in Papua (28,34\%).[2]

The data of Banjarmasin City Health Office Maternal Mortality Rate (AKI) in 2013 increased significantly $21 \%$ compared to 2012 at $16 \%$ and in 2014 there was a decrease in the number of maternal deaths $17 \%$, the cause of maternal death is mostly due to complications/labor i.e. preeclampsia/eclampsia and bleeding.[3]

Preliminary study results obtained data from the Department of Health of Banjarmasin city in 2016 from 26 Puskesmas in Banjarmasin there are 14,644 postpartum with delivery help by health personnel either doctor or midwife. Puskesmas Pekauman is the highest area of 1,301 postpartum mothers.[3] Puskesmas Pekauman shading 5 sub-district with 19 independent midwives, and 3 independent midwives such as independent midwives with the highest number of births in the work area Puskesmas Pekauman. Data delivery in 2015 at independent midwives TW as many as 183 deliveries, independent midwives A 165 labor and independent midwives M of 122 deliveries. Data about perineal wound healing and wound infection of the perineal suture were not found in the 3 independent midwives. From the results of discussions conducted on 10 postpartum women with perineal stitches suture in the work area Pekakesmas Pekauman Banjarmasin, 6 mothers experienced perineal wound healing $<6$ days, 3 women had perineal wound healing> 3 days and 1 mother had perineal wound healing $>6$ days.

\section{RESEARCH METHODS}

This research method uses quantitative analytic survey with research design CrossSectional, The population in this study were all postpartum maternal wound perineum I and II in the work area Pekakesmas Pekauman Banjarmasin Selatan in 2016 which amounted to 283 people. The sample of this research is taken using purposive sample technique with minimum sample size 30 people.

\section{a. Inclusion Criteria}

The inclusion criteria in this study were:

1) Postpartum who can read and write 
2) Postpartum who is not experiencing complications during the puerperium and requires referral

3) Puerperal mothers who have wound suture perineum of degree I and degree II

\section{b. Exclusion Criteria}

Exclusion criteria in this study no.

\section{RESULT}

\section{Analysis Univariate}

\section{Knowledge}

Table 1 Distribution Frequency of Respondents Based Knowledge

\begin{tabular}{clcc}
\hline No & Category & Frequency & Percentage $(\%)$ \\
\hline 1 & Good & 20 & 66,7 \\
2 & Enough & 8 & 26,7 \\
3 & Less & 2 & 6,7 \\
\hline & Amount & 30 & 100 \\
\hline
\end{tabular}

Based Table 1, can be seen from 30 respondents who studied postpartum mothers who have good knowledge as much as 20 respondents $(66,7 \%)$.

\section{Attitude}

Table 2 Distribution Frequency Respondents Based Attitude

\begin{tabular}{clcc}
\hline No & Category & Frequency & Percentage (\%) \\
\hline 1 & Positive & 27 & 90 \\
2 & Negative & 3 & 10 \\
\hline & Amount & 30 & 100 \\
\hline
\end{tabular}

Based Table 2, can be seen from 30 respondents who studied postpartum mothers who have a positive attitude as much as 27 respondents (90\%).

\section{Perineum Wound Healing}

Table 3 Distribution Frequency Respondents Based Perineum Wound Healing

\begin{tabular}{clcc}
\hline No & Category & Frequency & Percentage $(\%)$ \\
\hline 1 & Fast & 26 & 86,7 \\
2 & Slow & 4 & 13,3 \\
\hline & Jumlah & 30 & 100 \\
\hline
\end{tabular}

Based on Table 3, it can be seen from 30 respondents who studied there are healings of maternal perineum wounds as much as 26 respondents $(86,7 \%)$.

\section{Analysis Bivariate}

\section{Knowledge Analysis of Perineal Wound Healing}

Table 4 Analysis of postpartum maternal knowledge on perineal wound healing

\begin{tabular}{|c|c|c|c|c|c|c|c|}
\hline \multirow{3}{*}{$\begin{array}{c}\text { Knowle } \\
\text { dge }\end{array}$} & \multicolumn{4}{|c|}{$\begin{array}{c}\text { Perineal Wound } \\
\text { Healing }\end{array}$} & \multirow{2}{*}{\multicolumn{2}{|c|}{ Total }} & \multirow{3}{*}{$\begin{array}{l}p- \\
\text { val } \\
\text { ue }\end{array}$} \\
\hline & \multicolumn{2}{|c|}{ Rapid } & \multicolumn{2}{|c|}{ Slow } & & & \\
\hline & $\mathrm{N}$ & $\%$ & $\mathrm{~N}$ & $\%$ & $\mathrm{~N}$ & $\%$ & \\
\hline Good & 20 & 100 & 0 & 0 & 20 & 100 & \\
\hline Enough & 5 & 62,5 & 3 & 37,5 & 8 & 100 & 0,0 \\
\hline Less & 1 & 50 & 1 & 50 & 2 & 100 & 01 \\
\hline Total & 26 & 86,7 & 4 & 13,3 & 30 & 100 & \\
\hline
\end{tabular}

Based on table 4 it was found that postpartum mother who has good knowledge experience rapid wound healing perineum as many as 20 people (100\%), postpartum mother who has sufficient knowledge to heal rapid wound 5 people $(62,5 \%)$ while postpartum mothers who have less knowledge experience rapid healing wound 1 person $(50 \%)$.

The result of the statistical test by using Spearman Rank is obtained p- 
value 0,001 which means less than $\alpha$ value $(0,05)$ hence can be concluded $\mathrm{Ha}$ accepted mean there is the correlation between knowledge to perineum wound healing at a mother of postpartum in work area of Pekakesmas Pekauman South Banjarmasin.

Spearman Rank correlation value of 0.561 indicates that the direction of positive correlation with a strong correlation strength can be interpreted if the knowledge of postpartum mothers better to eat will be accompanied by rapid wound healing perineum.

\section{Attitude Analysis of Perineal Wound} Healing

Table 5 Analysis of postpartum parenting attitude to perineal wound healing

\begin{tabular}{|c|c|c|c|c|c|c|c|}
\hline \multirow{3}{*}{ Attitude } & \multicolumn{4}{|c|}{$\begin{array}{c}\text { Perineal Wound } \\
\text { Healing }\end{array}$} & \multirow{2}{*}{\multicolumn{2}{|c|}{ Total }} & \multirow{3}{*}{$\begin{array}{c}p- \\
\text { value }\end{array}$} \\
\hline & \multicolumn{2}{|c|}{ Rapid } & \multicolumn{2}{|c|}{ Slow } & & & \\
\hline & $\mathrm{N}$ & $\%$ & $\mathrm{~N}$ & $\%$ & $\mathrm{~N}$ & $\%$ & \\
\hline Positive & 24 & 88,9 & 3 & 11,1 & 27 & 100 & 0,003 \\
\hline Negative & 2 & 66,7 & 1 & 33,3 & 3 & 100 & 0,003 \\
\hline Total & 26 & 86,7 & 4 & 13,3 & 30 & 100 & \\
\hline
\end{tabular}

Based on table 5 it was found that postpartum women who had positive attitude experienced rapid healing of perineal wound as many as 24 people $(88,9 \%)$.

The result of the statistical test by using Spearman Rank is obtained pvalue 0,003 which means smaller than $\alpha$ value $(0,05)$ hence can be concluded that $\mathrm{Ha}$ accepted mean there is the correlation between attitude to perineal wound healing on postpartum in working area Puskesmas Pekauman South Banjarmasin.

Spearman Rank correlation value of 0.523 indicates that the direction of positive correlation with a strong correlation strength can be interpreted the better postpartum's attitude than the more rapid healing of the wound perineum.

\section{DISCUSSION}

\section{Analysis Univariate}

Research analysis between knowledge and postpartum attitude toward perineal wound healing in work area Pekakesmas Pekauman Banjarmasin Selatan, as follows:

\section{Knowledge}

Based on the researchers obtained the result that the knowledge of most respondents is good knowledge amounted to 20 (66.7\%) of respondents, this indicates that the puerperal mother knows well the healing of the perineal wound.

This study is similar to previous research $[4,5,14]$ which shows the result that the majority of respondents are well knowledgeable Puskesmas Mergangsan Yogyakarta. And there is a relationship between maternal post-natal knowledge about perineal wound care with wound healing process. There is also an association of nutritional status with 
wound healing process in Poly Kia hospital Panti Wilasa Semarang.

Knowledge of postpartum mother to heal wound perineum enough / less have inclination does not recover completely, the better the knowledge of the puerperal mother on the healing of the perineal wound will be faster the healing of her perineal wound. Lack of knowledge of how the perineal treatment will lead to infection and complications of postpartum mothers. When viewed from the results of research on the answers to the questionnaire that the occurrence of infections and complications of postpartum mother among them due to unfinished lochea expenditure, poor personal hygiene, slow perineal wound healing, poor nutrition and improper use of antiseptics for perineal wound care. This research is still the existence of respondents who are knowledgeable enough and less in tune with previous research $[5,14]$ showing that there is an influence of knowledge on perineal wound healing at Dr. Regional General Hospital. Zainoel Abidin Banda Aceh, marked by value $p$-value $0,001<\alpha$-value $(0,05)$. There is a nutritional effect on perineal wound healing at Dr. Regional General Hospital. Zainoel Abidin, marked by value $p$-value $0,002<\alpha$-value $(0,05)$. There is a personal hygiene effect on perineal wound healing at Dr. General Hospital. Zainoel Abidin Banda
Aceh, marked by value p-value 0,003 < $\alpha$-value $(0,05)$

\section{Attitude}

Based on the research, it was found that respondents' attitude toward perineal wound healing showed that 27 (90\%) respondents were positive.

This research is similar to the research $[6-8,18]$ with results of research showing the most positive attitude towards perineal wound healing at Khairunnisa Maternity Clinic. And there is a significant difference between the intervention group and the nonintervention group on knowledge, attitude, and behavior. Attitude determines decision-making for wound care.

Attitude is a factor that exists within the human being that can encourage or cause a certain behavior. Attitude is still a closed reaction, is not an open reaction. Attitude is a puerperal response in action. A good mother's attitude to the perineal wound healing will give birth to good behavior also in healing the perineum wound. Attitudes can be positive and can also be negative. A positive attitude of action tendency is approaching, love, expect, certain objects to stay away from, avoid, hate, or do not like certain objects. Postpartum maternal attitude towards perineal wound healing can be measured or 
known from the questionnaire that has been filled by postpartum. Attitude does not necessarily manifest in the form of action because for the action required another factor that is among others the facilities or facilities and infrastructure to obtain information. Judging from the results of the research on the questionnaire answers show that most respondents are positive and a small part is still negative toward the old personal hygiene wound healing perineum and traditional medicine in perineum wound care.

\section{Perineal Wound Healing}

Based on the research, it was found that healing wound perineum of degree I and II that run fast was $26(86,7 \%)$ respondents.

On the research result about the duration of wound healing perineum known that the degree I healed $<3$ days 4 respondents and II degree healed $<6$ days 22 respondents. This indicates that the perineal wound healing proceeds accordingly. Supported by previous studies [9-11,14-17] with the results of research that good wound healing depends on wound care and influenced by some other factors both internal and external. And began to improve perineal wound with the formation of new tissue covering the perineal wound within 6 days postpartum. The average stitch wound will be dry and good in less than a week. When the dirty blood came out the stench from the birth canal, hot mom and red stitch swelling wound, felt very painful or stitching wound it indicates infection.

\section{Knowledge Analysis of Perineal Wound Healing}

Based on research it can be seen that $20(100 \%)$ of respondents whose knowledge is good then perineal wound healing faster. The results of the analysis show that there is a relationship between maternal and parent's knowledge on perineal wound healing with $\mathrm{p}$-value 0,001 , the high knowledge possessed by the respondents will support them to be able to treat the perineal wound properly.

The results of this study are similar to previous studies [10-12,14] with the results of research showing that respondents who have good knowledge will have a good impact on perineum wound healing. And most have good knowledge with wound healing episiotomy $<7$ days. Statistical test results obtained p-value value $0.02(\alpha$ $<0.05$ ) indicates there is a relationship of maternal knowledge with wound healing episiotomy.

This can be due to several factors that affect knowledge one of them is information. Influence of information 
provided to a person even if the person has a low level of education but if the person is getting good information from various media then this can increase the knowledge of the person.

\section{Attitude Analysis Against Perineal}

\section{Wound Healing}

Based on the research note that 20 $(100 \%)$ of respondents who perineal wound healing run fast with good knowledge. The result of the analysis showed that there was a correlation between maternal and parent's knowledge on perineal wound healing with p-value 0,001, the high knowledge possessed by the respondent will support them to be able to treat the perineal wound properly so as not to cause infection on the perineal wound. With good knowledge can help respondents to know the various ways of healing perineum wound care faster.

The results of this study are reinforced by the theory of research [13] which says that one's knowledge is influenced by experience is an event that had experienced someone in interacting with the environment, there is a tendency for a bad experience someone will try to forget, but if the experience of the object is fun then psychologically will arise a very deep impression and imprint in emotions psychology and finally can also form a positive attitude in his life.

This research is similar to previous research $[4,7,18]$ with the result of research indicate that respondents who have a positive attitude will have a good effect also on perineal wound healing. Value p-value $0,004(\alpha<0,05)$. A positive attitude affects decision-making to perform wound care on the perineum which results in faster healing of the perineal wound.

Attitude is a factor that exists within the human being that can encourage or cause a certain behavior. If a mother has a good attitude towards herself then will cause good behavior also in the healing of a perineal wound.

\section{REFERENCES}

[1] Rahayu, YP, et al. 2012. Textbook Care of Babies and Breastfeeding Period. Jakarta: Mitra Discourse

[2] Ministry of Health of the Republic of Indonesia. 2015. Indonesia Health Profile. Jakarta: Ministry of Health RI.

[3] Banjarmasin City Health Office. 2016. Health Profile Banjarmasin City 2016. Health Office: Banjarmasin.

[4] Trisnawati. 2015. Factors Associated with Perineal Suture Perineal Wounds Suture at Postpartum Mother in Mergangsan Health Center Yogyakarta. 
[5] Suryati, et al. 2013. Relationship Knowledge Level Mother Postpartum About Perineal Wound Care And Nutritional Status With Wound Healing Process in Kia Poly RS Panti Wilasa Semarang.

[6] Boyle R, Hay-Smith EJ, Cody JD, Mørkved S. Pelvic floor muscle training for prevention and treatment of urinary and fecal incontinence in antenatal and postnatal women. Cochrane Database of Systematic Reviews 10 2012: CD007471.

[7] Risnawati, Venny. 2012. The Relationship between Postpartum Mother's Attitude to Balanced Nutrition Foods with Perineal Wound Healing at the Khairunnisa Maternity.

[8] Aisha. 2010. The Influence of Providing Health Care Package for Nutrition Maternal Care (PK-PIN) modified to Knowledge, Attitude and Behavior of Primary Postpartum Mothers in taking care of themselves in Palembang.

[9] Basuki, D and Luluk F. 2015. Description of the wound healing process perineum mother day 1 to 14 .

[10] Handayani, Y and Idriana, A. Factors Affecting Perineal Wound Healing In Postpartum Mother In District General Hospital Dr. Zainoel Abidin Banda Aceh.

[11] Handayani, Tita Septi. 2014. Factors Associated With Healing Episiotomy Injury in Work Area of Kandang Kecamatan Kampung Melayu Kota Bengkulu.

[12] Adelina, E C and Mangkuji, B. 2014. Relationship of Perineal Treatment To Perineum Wound Healing.

[13] Cehon, L, et al. 2007. Research Methods in Education. (Sixth edition). New York: Routledge.
[14] Johnson A, Thakar R, Sultan AH. Obstetric perineal wound infection: is there underreporting? British Journal of Nursing 21(5) 2012: S28, S30, S325.

[15] Kettle C., Dowswell T., and Ismail K.,: Absorbable stitches for repair of episiotomy and tears at childbirth. The Cochrane Library, Published Online: June 16. 2010

[16] Venkadalakshmi V, Venkatesan L., and Perdita H.,: Effect of Infrared Therapy on Episiotomy Pain and Wound Healing in Postnatal Mothers, Nursing Journal of Indian, VOL. Cl No. (9) 2011: 4-6.

[17] Kindberg S., Stehouwer,L., Hvidman T., and Henriksen: Postpartum perineal repair performed by midwives: a randomized trial comparing two suture techniques leaving the skin un sutured, BJOG: An International Journal of Obstetrics \& Gynecology 2008;115 (4): 472479.

[18] Cioffi jane, dkk. Clinical DecisionMaking for Repair of Spontaneous Childbirth Trauma: Validation of Cues and Related Factors (Journal of Midwifery \& Women's Health). American College of NurseMidwives: Elsevier Inc. 2009. 